\title{
Response Surface Methodology Optimization of Thebaine Biotransformation into Codeine and Morphine Using Bacillus sp. FAR
}

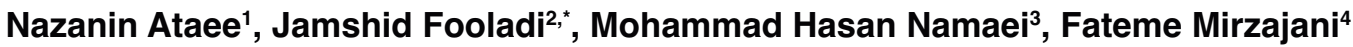 \\ 1Department of Microbiology, Faculty of Biological Science, Alzahra University, Vanak, Tehran, IRAN. \\ ${ }^{2}$ Department of Biotechnology, Faculty of Biological Science, Alzahra University, Vanak, Tehran, IRAN. \\ ${ }^{3}$ Birjand Infectious Diseases Research Center, Birjand University of Medical Sciences, Ghafary Ave., Birjand, IRAN. \\ ${ }^{4}$ Departmrnt of Nanobiotechnology, Protein Research Center (PRC), Shahid Beheshti University, G.C., Tehran, IRAN.
}

\begin{abstract}
Background: Codeine and morphine are important pharmaceuticals having analgesic characteristics. Aim: The current study used response surface methodology to optimize the biotransformation of thebaine into codeine and morphine using Bacillus sp. FAR. Methods: A central composite design was used to determine the optimal concentrations of buffer and thebaine, $\mathrm{pH}$, time, temperature, and biomass. Improvement in transformation was monitored using HPLC-DAD. Results: The optimized conditions employed were $\mathrm{pH}$ 7.7 at $36^{\circ} \mathrm{C}$ for $30 \mathrm{~h}$ using a thebaine concentration of $80 \mu \mathrm{g} / \mathrm{mL}, 45 \mathrm{mM}$ tris of buffer and $2.9 \% \mathrm{w} / \mathrm{v}$ biomass. The optimal conditions for codeine and morphine production were 2.995 and $1.113 \mu \mathrm{g}$, respectively. Conclusion: Optimization demonstrated that $\mathrm{pH}$ and biomass had the strongest effects on biotransformation.
\end{abstract}

Key words: Biotransformation, CCD, Codeine, Morphine, Thebaine, Bacillus.

\section{INTRODUCTION}

The structure and activity of alkaloids are of concern. ${ }^{1}$ Morphine and codeine are significant natural pharmaceuticals having powerful analgesic properties. ${ }^{2-7}$ The synthesis of morphine alkaloids dates back about 150 years; however their molecular complexity. ${ }^{8}$ with five chiral centers ${ }^{9,10}$ means that morphine and its analogues have not been investigated from a fully synthetic chemistry approach. ${ }^{11}$ The available chemical methods suffer from low yield and produce hazardous waste. ${ }^{1}$ Until recently, Papaver somniferum ,the opium poppy, ${ }^{12}$ has been the only source of production for morphine and its derivatives. ${ }^{2-9-18}$ The World Drug Report of 2015 on narcotic drugs states that global opium production reached 7554 tons in 2014 and worldwide consumption is increasing.

Because of illicite use, cultivation of the opium poppy continues ${ }^{4}$ therefore, it is necessary to find other sources for morphine and codeine ${ }^{2-19}$ The non-narcotic thebaine, the main alkaloid of P. bracteatum, ${ }^{20}$ has been a focus of attention because it accumulates thebaine with no morphine and codeine. ${ }^{21}$ Thebaine is an excellent starting material for synthesis of diverse morphine agonists and antagonists. ${ }^{1-22}$ In recent years, microbial production of secondary plant metabolites as an alternative method of synthesis of such effective compounds has been of increased interest. ${ }^{10-18}$ Microbial transformation is the modification of certain compounds by enzymatic reactions ${ }^{22}$ to achieve specific and useful metabolite accumulation through environmentally harmless and simpler bioprocesses. ${ }^{23}$ Selecting microbial reactions directed toward the native plant hosts as alternative to chemical synthesis employed in traditional methods offers benefits such as quick accumulation of biomass, production of main intermediate molecules separately,
Submission Date: 29-01-2017; Revision Date: 15-03-2017; Accepted Date: 30-03-2017

DOI: 10.5530/ijper.51.4.101 Correspondence: Jamshid Fooladi, Department of Biotechnology, Faculty of Biological Science, Alzahra University, Vanak, Tehran, IRAN. Tel.no: +98-21 88058912 E-mail: ataee1357@yahoo. com

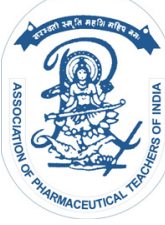

www.ijper.org 
simplicity of purification and accessibility of genetic tools for additional optimization. ${ }^{8}$

Many studies have examined microbial transformation of the morphine alkaloids using biocatalysts ${ }^{24,25}$ such as the genus Trametes, ${ }^{22-25-32}$ Cunninghamella, ${ }^{25-27-34}$ Mucor piriformis, 22-24-26,27-30 and Cylindrocarpon didymium ${ }^{24-30-35}$ fungi and Arthrobactersp, ${ }^{25-27-30-32-36}$ Pseudomonas testosterone, ${ }^{24,25-27-30-32-37}$ Pseudomonas putida. ${ }^{3-24-28-30,31}$ Bacillus, ${ }^{24-27-30}$ Mycobacterium neoaurum, ${ }^{27-29,30}$ Streptomyces 25-27-29-32 and Nostoc muscorum $^{27,28}$ bacteria. Few reports exist about microbial metabolism of thebaine; the first on thebaine biotransformation appeared in the $1960 \mathrm{~s}^{25}$ Some reports explained transformation by Tramete sanguinea, which converts thebaine into 14-hydroxycodeinone and 14-hydroxycodeine. ${ }^{22-25}$ It was also found that the main product of thebaine by Mucor piriformis is northebaine. ${ }^{22}$ Thebaine transformation using Cunninghamella echinulata into northebaine has also been investigated. ${ }^{22}$

In our previous research, we isolated new biocatalyst from P.bracteatum microflora to produce morphine and codeine spontaneously. ${ }^{38}$ In this study central composite design (CCD) methodology has been applied for improvement the yield of codeine and morphine, in thebaine biotransformationusing whole cell catalyst, Bacillus sp. FAR.

\section{MATHERIAL METHODS}

\section{Biocatalyst production}

A bacterial strain of P. bracteatum microflora has the ability to transform thebaine into morphine and codeine which was reported previously. The Bacillus sp. FAR (accession number KU746803; GenBank NCBI) has been detailed and completed ${ }^{38}$ For preculture preparation of Bacillus sp. FAR, the stock was grown in $100 \mathrm{ml}$ of complex medium containing $15 \mathrm{~g} / 1$ glucose, $10 \mathrm{~g} / 1$ pepton, $5 \mathrm{~g} / 1$ yeast extract, $2 \mathrm{~g} / 1 \mathrm{NaCl}, 0.5 \mathrm{~g} / 1 \mathrm{~K}_{2} \mathrm{HPO}_{4}$ and $0.2 \mathrm{~g} / \mathrm{l}$ $\mathrm{MgSO}_{4} .7 \mathrm{H}_{2} \mathrm{O}\left(\mathrm{pH}\right.$ 6.8) and incubated at $30^{\circ} \mathrm{C}$ and $140 \mathrm{rpm}$. Thereafter, $30 \mathrm{ml}$ of cell suspension with an optical density of 0.1 at $620 \mathrm{~nm}$ was used to inoculate $270 \mathrm{ml}$ of complex medium, which was then incubated under $140 \mathrm{rpm}$ for $4 \mathrm{~h}$ at $30^{\circ} \mathrm{C}$. The initial working volume of 2.71 of complex medium (in a 51 bioreactor) was inoculated with Bacillus sp. FAR (10\% v/v). The batch culture was created and the main physical and chemical parameters of agitation rate, air transfer, temperature, $\mathrm{pH}$ and foam production were controlled. In brief, the initial stirring frequency was $200 \mathrm{rpm}$, $1 \mathrm{v} / \mathrm{v} / \mathrm{min}$ sterile air was a passed through the bioreactor at $30{ }^{\circ} \mathrm{C}$ and the $\mathrm{pH}$ was maintained at 6.8. Samples were withdrawn every $30 \mathrm{~min}$ over a period of $5 \mathrm{~h}$ and the biomass turbidity of the culture was monitored at $620 \mathrm{~nm}$.

The main fuction of a bioreactor is to supply high cell biomass concentrations needed for biotransformation. The bioreactor was allowed to proceed until the cells reached the stationary phase of growth and the process ceased at $5 \mathrm{~h}$. The biomass from the early stationary phase of growth in complex medium was harvested (12000 g, $20 \mathrm{~min}, 4^{\circ} \mathrm{C}$ ) and washed twice with sterile saline solution and stored at $-40^{\circ} \mathrm{C}$. These pellets were used directly for biotransformation assays.

\section{Optimization by Design Expert}

Design Expert 7.0.0 was used for the experimental design and statistical analysis to predict the maximum biotransformation of thebaine into codeine and morphine. The parameters affecting biotransformation at five levels were thebaine concentration, biomass weight, tris-buffer concentration, temperature, incubation period time, and $\mathrm{pH} . \mathrm{A}, \mathrm{B}, \mathrm{C}, \mathrm{D}, \mathrm{E}$, and $\mathrm{F}$ denote $\mathrm{pH}$, temperature, time, substrate, biomass and buffer, respectively. Table 1 shows the actual and coded values of the independent factors over 80 experiments (64 cube point, 12 star point and 4 center point) designed the factors and value shown in Table 1.

\section{Biotransformation and HPLC analysis}

The biotransformation reactions were initiated by adding the desired amount of cells and thebaine to $50 \mathrm{ml}$ of tris base buffer according to the experimental design. These cultures were incubated at $140 \mathrm{rpm}$ for different times. Thereafter, the supernatant (centrifugation $8000 \mathrm{~g}$, $20 \mathrm{~min}, 4^{\circ} \mathrm{C}$ ) were tested for codeine and morphine production by HPLC-DAD.

Each sample was dissolved in aqueous acetonitrile 68\% (v/v), and analyzed using an HPLC (Knauer; Germany) equipped with a C18 column $(250 \mathrm{~mm} \times 4.6 \mathrm{~mm} \times 5 \mu \mathrm{m}$ $\times 100 \mathrm{~A}^{\circ}$ ). The flow rate was $1 \mathrm{ml} / \mathrm{min}$ and gradient washing using $\mathrm{A}\left(\mathrm{H}_{2} \mathrm{O}, 0.5 \%\right.$ acetic acid, $1 \%$ TEA) and $\mathrm{B}$ (acetonitrile) was performed. Separation occurred for solvent $\mathrm{A}$ and showed the percentage of decrease to $60 \%$ and $50 \%$ in 10 and 20 min, respectively. Thereafter, solvent A increased to $100 \%$ in $7 \mathrm{~min}$ and separation ceased by $30 \mathrm{~min}$. An aliquot $(20 \mu \mathrm{l})$ of sample was injected into the HPLC and analysis was carried out at $30^{\circ} \mathrm{C}$ at a detection wavelength of $280 \mathrm{~nm}$. The calibration of codeine and morphine was performed at six concentraions $(2-10 \mathrm{ng} / \mathrm{ml})$ in three replications. The linear dynamic range equation, LOD and LOQ for codeine were $\mathrm{Y}=6114.7 \mathrm{x}-10769, \mathrm{R}^{2}=0.9698,0.12$ and $0.41 \mathrm{ng} / \mathrm{g}$ and for morphine were $\mathrm{Y}=1635 \mathrm{x}+2501.5$, $\mathrm{R}^{2}=0.9699,0.21$ and $0.71 \mathrm{ng} / \mathrm{g}$. 


\section{RESULTS AND DISCUSSION}

In view of the difficulties associated with synthetic routes for morphine alkaloids, the current project examined the biological transformation of thebaine into codeine and morphine. From Previous results it found that Bacillus sp. FAR has the ability to convert thebaine into codeine and morphine (38). This study optimized the factors for codeine and morphine production from thebaine biotransformation using Design Expert software and response surface methodology by resting cells of Bacillus sp. FAR. To our knowledge, there have been no reports decribing this transformation functionality.

To determine the growth rate of bacteria, the optical density of the culture and the biomass weight were measured every $30 \mathrm{~min}$. The growth was carried out in a bioreactor to achieve maximum cell concentration in the early stationary phase. A large quantity of resting cells of Bacillus sp. FAR (50 g wet cells in $\mathrm{I}^{-1}$ over $5 \mathrm{~h}$ ) in the early stationary phase was harvested and used for biotransformation processes. Approximately $150 \mathrm{~g}$ of metabolically active resting cells of Bacillus sp. FAR were obtained in the early stationary phase and examined for optimization over the course of the 80 experiments.

Response surface methodology was used to predict the best conditions for thebaine transformation into codeine and morphine. Several factors contribute to the reaction, including thebaine concentration, biomass weight, tris buffer concentration, temperature, incubation period time and $\mathrm{pH}$. The experimental design of the data was carried out using Design Expert software 7.0.0. The levels of the factors and the proposed 80 experiments are shown in Table 2. Each experiment was analyzed using HPLC-DAD based on the previous section. The metabolite peaks were identified by comparison with their HPLC retention and on the similarity of UV spectra Figure 1. The results for HPLC retention of morphine and codeine were 10.61 and $14.4 \mathrm{~min}$, respectively. The correlation coefficient $\left(\mathrm{R}^{2}\right)$ showed that variations in the experimental response with the regression model are in compliance. The $\mathrm{R}^{2}$ of biotransformation $(0.7502)$ and the adjusted $R^{2}(0.7223)$ indicate that the model and experiment were well-fitted. This model showed a standard deviation (SD) of 0.18 and a mean of 0.71 . ANOVA results of the optimization study show the significance of the model at $\mathrm{p}<0.001$ Table 3 . There is only a $0.01 \%$ probability of a model F-value resulting from noise. A value of $\mathrm{F}<0.0001$ indicates that the model terms are significant. In this case, interactions between buffer, $\mathrm{pH}$, temperature, biomass and time were significant. For lack of fit, $\mathrm{p}=0.4$ and was not significant. A non-significant lack of fit indicates that the experimental and mathematical models fit. These results show sufficient validation of the model Table 3 . ANOVA results for the mathematical model equation in Table 3 show significant results for biotransformation of the process variables of $\mathrm{pH}$ and biomass. The factors for optimization were set at experimental ranges designed for maximum desirability. The effects of their interaction with thebaine biotransformation were studied by plotting 3D surface curves. Figure 2 shows the curves for codeine and morphine production response surface optimization. Note that, in each plot, two factors were studied and four were held constant at central values.

The software found that optimal conditions were a $\mathrm{pH}$ of 7.7 at $36^{\circ} \mathrm{C}$ for $30 \mathrm{~h}$ with a substrate concentration of $80 \mu \mathrm{g} / \mathrm{ml}$, biomass of $2.29 \% \mathrm{w} / \mathrm{v}$ and tris buffer concentration of $45 \mathrm{mM}$. Decreases in buffer concentration (F) and substrate concentration (D) increased the production of codeine and morphine. These plots show that morphine alkaloid production increased as temperature (B) increased to $32^{\circ} \mathrm{C}$ and thereafter decreased

\begin{tabular}{|l|c|c|c|c|c|c|}
\hline \multicolumn{7}{|c|}{ Table 1: Design factor values } \\
\hline Factors & Unit & $\mathbf{- 2}$ & $\mathbf{- 1}$ & $\mathbf{0}$ & $\mathbf{1}$ & $\mathbf{2}$ \\
\hline $\mathrm{A}: \mathrm{pH}$ & - & 5.5 & 6.5 & 7.5 & 8.5 & 9.5 \\
\hline $\begin{array}{l}\text { B: } \\
\text { Temperature }\end{array}$ & ${ }^{\circ} \mathrm{C}$ & 28 & 32 & 36 & 40 & 44 \\
\hline C: Time & $\mathrm{h}$ & 15 & 25 & 25 & 30 & 35 \\
\hline D: Substrate & $\mu \mathrm{g} / \mathrm{ml}$ & 20 & 40 & 60 & 80 & 100 \\
\hline E: Biomass & $\begin{array}{c}\mathrm{g} / 50 \\
\mathrm{ml}\end{array}$ & 0.5 & 1 & 1.5 & 2 & 2.5 \\
\hline F: Buffer & $\mathrm{mM}$ & 25 & 40 & 55 & 70 & 85 \\
\hline
\end{tabular}

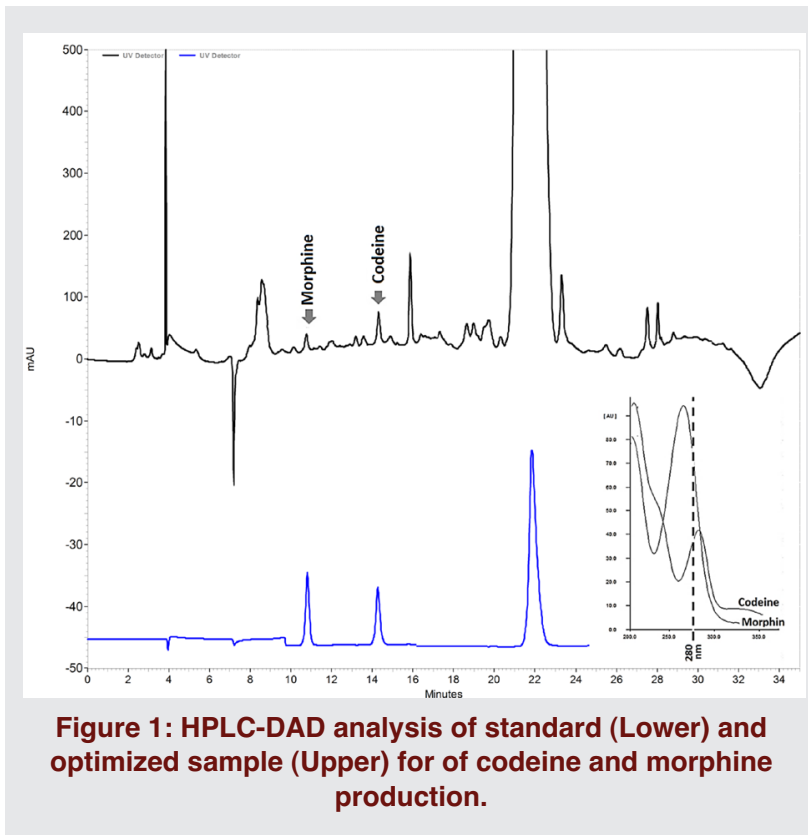


Table 2: Central composite design and response for codeine and morphine production after biotransformation by Bacillus sp. FAR. The best codeine and morphine were in runs 32 and 41 , respectively

\begin{tabular}{|c|c|c|c|c|c|c|c|c|c|c|c|c|c|c|c|}
\hline$\stackrel{5}{\bar{z}}$ & 동 & 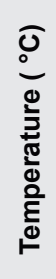 & $\begin{array}{l}\bar{\Xi} \\
\stackrel{\Xi}{\xi} \\
\underline{\xi}\end{array}$ & 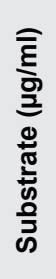 & 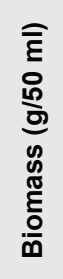 & 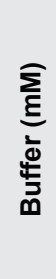 & 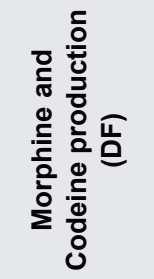 & $\stackrel{\overline{\underline{\alpha}}}{\overline{\underline{x}}}$ & I & 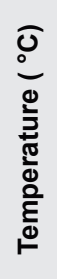 & $\begin{array}{l}\bar{\Xi} \\
\stackrel{\Xi}{\xi} \\
\underline{\xi}\end{array}$ & 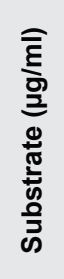 & 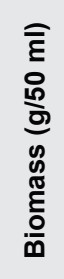 & 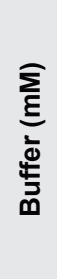 & 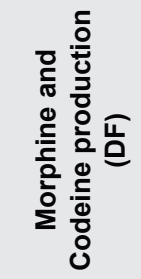 \\
\hline 1 & 6.50 & 40 & 30 & 40 & 1 & 40 & 0.000028 & 41 & 6.50 & 32 & 20 & 40 & 2 & 40 & 12.531288 \\
\hline 2 & 8.50 & 32 & 30 & 40 & 2 & 70 & 0.002847 & 42 & 6.5 & 40 & 30 & 80 & 2 & 70 & 0.591183 \\
\hline 3 & 6.50 & 40 & 20 & 80 & 2 & 40 & 0.002847 & 43 & 6.5 & 40 & 20 & 80 & 1 & 70 & 0.162233 \\
\hline 4 & 8.50 & 32 & 30 & 80 & 1 & 40 & 0.446487 & 44 & 6.5 & 40 & 30 & 40 & 2 & 40 & 1.043369 \\
\hline 5 & 6.50 & 32 & 20 & 40 & 1 & 40 & 0.102968 & 45 & 9.5 & 36 & 25 & 60 & 1.5 & 55 & 0.000028 \\
\hline 6 & 7.50 & 44 & 25 & 60 & 1.5 & 55 & 0.253844 & 46 & 8.5 & 40 & 30 & 80 & 2 & 70 & 1.438769 \\
\hline 7 & 6.50 & 40 & 20 & 80 & 2 & 70 & 0.361297 & 47 & 8.5 & 32 & 20 & 80 & 1 & 40 & 0.000028 \\
\hline 8 & 8.50 & 32 & 30 & 80 & 2 & 70 & 0.232428 & 48 & 7.5 & 36 & 25 & 20 & 1.5 & 55 & 4.612207 \\
\hline 9 & 7.50 & 36 & 25 & 60 & 1.5 & 55 & 0.114936 & 49 & 8.5 & 32 & 30 & 80 & 2 & 40 & 3.985770 \\
\hline 10 & 6.50 & 40 & 30 & 80 & 2 & 40 & 4.307277 & 50 & 6.5 & 40 & 20 & 40 & 1 & 40 & 0.001040 \\
\hline 11 & 6.50 & 36 & 25 & 60 & 2.5 & 55 & 0.112331 & 51 & 8.5 & 40 & 20 & 40 & 1 & 70 & 0.000028 \\
\hline 12 & 6.50 & 32 & 30 & 40 & 2 & 70 & 1.075755 & 52 & 5.5 & 36 & 25 & 60 & 1.5 & 55 & 0.001040 \\
\hline 13 & 8.50 & 32 & 30 & 40 & 1 & 40 & 0.229895 & 53 & 8.5 & 32 & 20 & 40 & 1 & 40 & 0.001040 \\
\hline 14 & 7.50 & 36 & 15 & 60 & 1.5 & 55 & 2.131466 & 54 & 6.5 & 32 & 20 & 80 & 2 & 40 & 0.437404 \\
\hline 15 & 8.50 & 32 & 20 & 80 & 2 & 40 & 0.826197 & 55 & 6.5 & 32 & 30 & 80 & 2 & 40 & 0.000028 \\
\hline 16 & 6.50 & 32 & 30 & 40 & 1 & 70 & 0.001040 & 56 & 6.5 & 40 & 20 & 40 & 2 & 70 & 0.561739 \\
\hline 17 & 6.50 & 40 & 20 & 40 & 2 & 40 & 0.448894 & 57 & 6.5 & 32 & 20 & 80 & 1 & 70 & 1.278751 \\
\hline 18 & 8.50 & 40 & 30 & 40 & 1 & 40 & 1.024827 & 58 & 6.5 & 32 & 20 & 40 & 2 & 70 & 0.952792 \\
\hline 19 & 6.50 & 32 & 20 & 40 & 1 & 70 & 0.002847 & 59 & 6.5 & 40 & 20 & 40 & 1 & 70 & 0.002847 \\
\hline 20 & 6.50 & 40 & 30 & 40 & 1 & 70 & 0.002847 & 60 & 8.5 & 40 & 20 & 80 & 2 & 40 & 3.472798 \\
\hline 21 & 8.50 & 32 & 30 & 80 & 1 & 70 & 0.474166 & 61 & 6.5 & 32 & 30 & 40 & 2 & 40 & 0.000028 \\
\hline 22 & 8.50 & 40 & 20 & 40 & 2 & 40 & 2.132454 & 62 & 8.5 & 40 & 20 & 80 & 2 & 70 & 0.000028 \\
\hline 23 & 6.50 & 32 & 30 & 40 & 1 & 40 & 0.000028 & 63 & 6.5 & 40 & 30 & 80 & 1 & 70 & 0.001040 \\
\hline 24 & 8.50 & 32 & 20 & 80 & 2 & 70 & 0.639461 & 64 & 8.5 & 32 & 30 & 40 & 2 & 40 & 0.001040 \\
\hline 25 & 8.50 & 32 & 30 & 40 & 1 & 70 & 0.351788 & 65 & 6.5 & 32 & 30 & 80 & 1 & 70 & 0.324141 \\
\hline 26 & 7.50 & 36 & 35 & 60 & 1.5 & 55 & 4.826464 & 66 & 8.5 & 40 & 30 & 40 & 1 & 70 & 0.001040 \\
\hline 27 & 8.50 & 32 & 20 & 40 & 2 & 70 & 0.612325 & 67 & 7.5 & 36 & 25 & 60 & 1.5 & 55 & 3.149857 \\
\hline 28 & 7.50 & 36 & 25 & 60 & 0.5 & 55 & 2.963731 & 68 & 8.5 & 40 & 20 & 80 & 1 & 40 & 0.002847 \\
\hline 29 & 6.50 & 32 & 30 & 80 & 2 & 70 & 0.369130 & 69 & 7.5 & 36 & 25 & 60 & 1.5 & 55 & 3.621635 \\
\hline 30 & 8.50 & 40 & 30 & 80 & 2 & 40 & 2.632886 & 70 & 7.5 & 36 & 25 & 100 & 1.5 & 55 & 2.527428 \\
\hline 31 & 6.50 & 32 & 30 & 80 & 1 & 40 & 0.337888 & 71 & 6.5 & 32 & 20 & 80 & 2 & 70 & 0.001040 \\
\hline 32 & 7.50 & 36 & 25 & 60 & 1.5 & 55 & 18.589700 & 72 & 8.5 & 40 & 20 & 40 & 1 & 40 & 0.000028 \\
\hline 33 & 8.50 & 32 & 20 & 80 & 1 & 70 & 0.000028 & 73 & 8.5 & 40 & 30 & 80 & 1 & 40 & 0.614602 \\
\hline 34 & 8.50 & 40 & 30 & 40 & 2 & 70 & 1.487322 & 74 & 7.5 & 28 & 25 & 60 & 1.5 & 55 & 0.351165 \\
\hline 35 & 6.50 & 40 & 20 & 80 & 1 & 40 & 1.761946 & 75 & 6.5 & 40 & 30 & 80 & 1 & 40 & 0.000028 \\
\hline 36 & 6.50 & 40 & 30 & 40 & 2 & 70 & 0.000028 & 76 & 8.5 & 32 & 20 & 40 & 1 & 70 & 0.020332 \\
\hline 37 & 6.50 & 32 & 20 & 80 & 1 & 40 & 0.376892 & 77 & 7.5 & 36 & 25 & 60 & 1.5 & 25 & 4.601180 \\
\hline 38 & 8.50 & 40 & 30 & 80 & 1 & 70 & 0.790706 & 78 & 8.5 & 32 & 20 & 40 & 2 & 40 & 0.830354 \\
\hline 39 & 8.50 & 40 & 20 & 80 & 1 & 70 & 0.002847 & 79 & 8.5 & 40 & 30 & 40 & 2 & 40 & 0.001040 \\
\hline 40 & 8.50 & 40 & 20 & 40 & 2 & 70 & 0.000028 & 80 & 7.5 & 36 & 25 & 60 & 1.5 & 85 & 2.911799 \\
\hline
\end{tabular}




\begin{tabular}{|c|c|c|c|c|c|c|}
\hline Source & Sum of Squares & df & Mean Square & F Value & \multicolumn{2}{|c|}{ p-value Prob > F } \\
\hline Model & 2.821705 & 18 & 0.156761 & 5.014425 & $<0.0001$ & significant \\
\hline A-pH & 0.003602 & 1 & 0.003602 & 0.115229 & 0.7354 & \\
\hline B-Temperature & 0.007605 & 1 & 0.007605 & 0.243267 & 0.6236 & \\
\hline C-Time & 0.008238 & 1 & 0.008238 & 0.263505 & 0.6096 & \\
\hline D-Substrate & 0.077795 & 1 & 0.077795 & 2.488469 & 0.1199 & \\
\hline E-Biomass & 0.020063 & 1 & 0.020063 & 0.641781 & 0.4262 & \\
\hline F-Buffer & 0.135105 & 1 & 0.135105 & 4.321696 & 0.0418 & \\
\hline AC & 0.223847 & 1 & 0.223847 & 7.16035 & 0.0096 & \\
\hline AD & 0.033293 & 1 & 0.033293 & 1.064952 & 0.3062 & \\
\hline BD & 0.028063 & 1 & 0.028063 & 0.897677 & 0.3471 & \\
\hline BF & 0.027707 & 1 & 0.027707 & 0.886269 & 0.3502 & \\
\hline CD & 0.090442 & 1 & 0.090442 & 2.893025 & 0.0941 & \\
\hline DE & 0.053624 & 1 & 0.053624 & 1.7153 & 0.1952 & \\
\hline DF & 0.036542 & 1 & 0.036542 & 1.168878 & 0.2839 & \\
\hline EF & 0.040975 & 1 & 0.040975 & 1.310688 & 0.2567 & \\
\hline$A^{\wedge} 2$ & 0.895994 & 1 & 0.895994 & 28.66073 & $<0.0001$ & \\
\hline $\mathrm{B}^{\wedge} 2$ & 0.846302 & 1 & 0.846302 & 27.0712 & $<0.0001$ & \\
\hline$E^{\wedge} 2$ & 0.36861 & 1 & 0.36861 & 11.79096 & 0.0011 & \\
\hline $\mathrm{F}^{\wedge} 2$ & 0.051119 & 1 & 0.051119 & 1.635169 & 0.2058 & \\
\hline Residual & 1.906987 & 61 & 0.031262 & & & \\
\hline Lack of Fit & 1.846739 & 58 & 0.03184 & 1.585458 & 0.4019 & not significant \\
\hline Std. Dev. & 0.017681 & & R-S & & 0.7502 & \\
\hline C.V. \% & 24.75555 & & Adj $R$ & ared & 0.7223 & \\
\hline
\end{tabular}

(Biotransformation Product) $0.1=-20.58968+2.17339 \mathrm{pH}+0.74271 \times$ Temperature- $0.11341 \times$ Time $-0.34016 \times$ Substrate $+1.63153 \times$ Biomass $+0.039245 \times$ Buffer +0.011828 $\times \mathrm{pH} \times$ Time $+0.022808 \times \mathrm{pH} \times$ Substrate $+5.23503 \mathrm{E}-003 \times$ Temperature $\times$ Substrate $-3.46777 \mathrm{E}-004 \times$ Temperature $\times$ Buffer+7.51839E-003 $\times$ Time $\times$ Substrate $-0.057892 \times$ Substrate $\times$ Biomass-1.59299E-003 $\times$ Substrate $\times$ Buffer-3.37371E-003 $\times$ Biomass $\times$ Buffer-0.16964 $\times$ pH2-0.010304 $\times$ Temperature2 $-0.43523 \times$ Biomass2 $-1.80087 \mathrm{E}-004$ $\times$ Buffer2
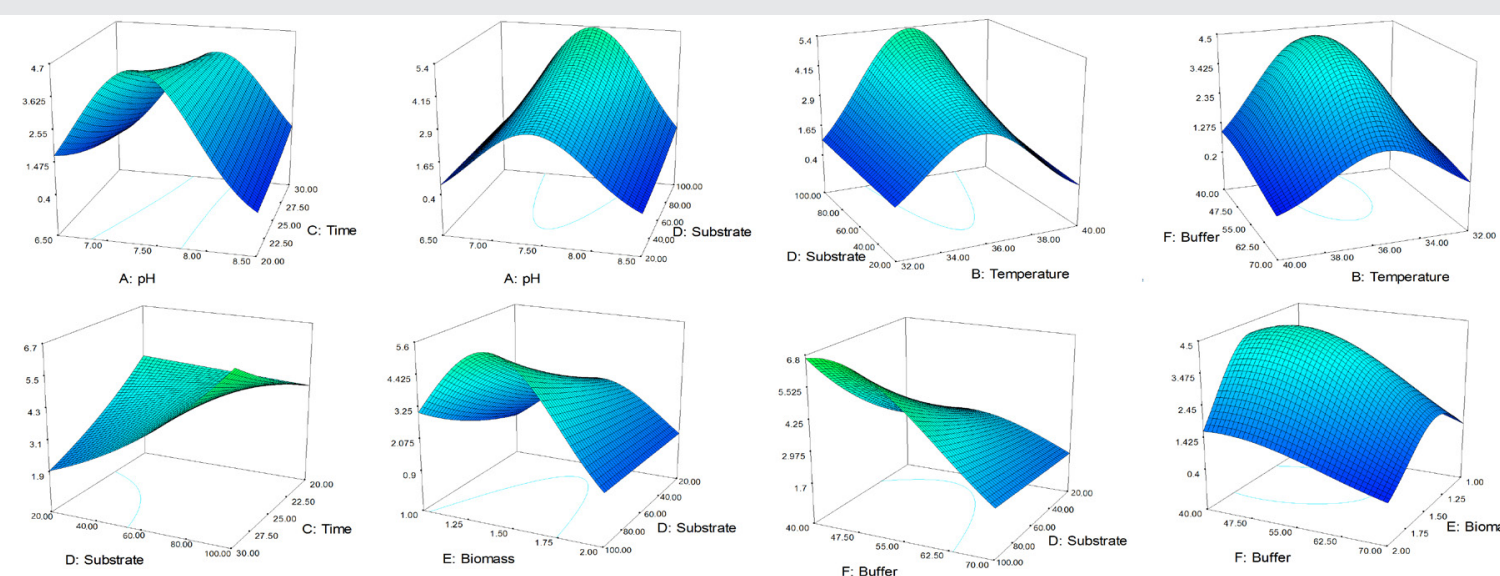

Figure 2: Relationships of each factor within the central terms of other factors for codeine and morphine production vs response rates of other factors (A: $\mathrm{pH}, \mathrm{B}$ : temperature, C: time, $\mathrm{D}$ : substrate concentration, $\mathrm{E}$ : biomass, F: buffer concentration). 
with a further increase in temperature. The same trend was observed for codeine and morphine production in thebaine biotransformation on acidity $(\mathrm{pH})$ and biomass. An increase in $\mathrm{pH}$ from 5.5 to 7.5 and of biomass from 0.5 to $2 \mathrm{~g}$ increased codeine and morphine production, but further increases in either factor decreased biotransformation activity. The optimal conditions for $\mathrm{pH}$, temperature and biomass fell in the middle of the ranges investigated. In other words, decreases or increases in these factors decreased codeine and morphine production. The microbial transformation of thebaine into other morphine alkaloids appears to be a multistep process which requires more than one enzyme. The secondary metabolite biosynthetic pathway in plants is branched and complicated..$^{10}$ In $P$. somniferum, morphine alkaloids are produced in sieve elements and then transported to laticifers for storage. In contrast to intact plants, opium poppy cell cultures do not produce morphine alkaloids. ${ }^{39}$ In general, thebaine is an extremely metabolically inert compound; out of 230 plants so far tested, it is converted by only two species to metabolites. ${ }^{40}$ Despite the complicated and difficult pathway to reconstruction of a microbial production system, ${ }^{10}$ it is interesting to note that this biotransformation of thebaine to codeine and morphine was performed in one microbial cell.

The low yield of this transformation may result from the complexity and inert aromatic nature of thebaine, the intricate association of multiple protein subunits and the presence of cofactors and electron donors (NADPH, ATP, etc.), ${ }^{41}$ expression of low levels of enzymes, ${ }^{34}$ substrate/product inhibited biotransformation, ${ }^{34}$ lack of membrane transport processes involved to move the substrate into the site where the enzymes are known to be located, ${ }^{8-34}$ and enzymes exhibiting a high tolerance of a substrate. ${ }^{11}$ Another factor that may limit conversion is the lack of an intracellular component for storage of products at the same laticifers in $P$. somniferum. It appears that resting cells of Bacillus sp. FAR do not fully consume thebaine. Further work on the production of codeine and morphine for yield improvement through protein engineering strategies is proposed.

\section{CONCLUSION}

Optimal conditions for codeine and morphine production from thebaine transformation by the gram-positive bacterium belonging to the genus Bacillus was investigated. The results of 80 optimization experiments on thebaine transformation using active resting cells of Bacillus sp. FAR showed that the optimal yields of codeine and morphine production were 2.995 and
$1.113 \mu \mathrm{g}$, respectively. The effect of buffer, $\mathrm{pH}$, temperature, biomass and interactional $\mathrm{pH}$ and time were significant. Despite its low yield of codeine and morphine, this new biocatalyst offers a source for production that is harmless resource in comparison with the opium poppy.

\section{ACKNOWLEDGMENT}

Financial support from the Research Council of Alzahra Universityis gratefully acknowledged. It is our honor to thank technical advising of colleagues at Medicinal Plants and Drug Research Institute of Shahid Beheshti University, Tehran, IRAN. This publication represents a component of the PhD thesis of Nazanin Ataee at the faculty of Microbiological Science of Alzahra University, Tehran, IRAN.

\section{CONFLICT OF INTEREST}

The authors declare that they have no conflicts of interest.

\section{ABBREVIATION USED}

CCD: Central Composite design; NCBI: National Center for Biotechnology Information; LOD: Limit of Detection; LOQ: Limit of Quantification; SD: Standard Deviation.

\section{REFERENCES}

1. Rathbone DA, Lister DL, Bruce NC. Biotransformation of alkaloids. The alkaloids: Chemistry and Biology. 2002;58:1-82. https://doi.org/10.1016/ s0099-9598(02)58002-0.

2. Salehi P, Sonboli A, Zavareh AF, Sefidkon F, Cheraghi B, Dayeni M. Narcotic alkaloids of four Papaver species from IRAN. Zeitschrift Für Naturforschung C. 2007;62(1-2):16-8. https://doi.org/10.1515/znc-2007-1203 ; PMid:17425099.

3. Lister DL, Kanungo G, Rathbone DA, Bruce NC. Transformations of codeine to important semisynthetic opiate derivatives by Pseudomonas putida m10. FEMS Microbiology Letters. 1999;181(1):137-44. https://doi. org/10.1111/j.1574-6968.1999.tb08836.x ; PMid:10564799.

4. Dehghan E, Hosseini B, Badi NH, Ahmadi SF. Application of conventional and new biotechnological approaches for improving of morphinane alkaloids production. Journal of Medicinal Plants. 2010;3(35):33-50.

5. Jagtap A, Bhaskar M. Evaluation of Antidepressant and Antinociceptive Activity of Escitalopram. Indian Journal of Pharmacy Education and Research. 2013;47(1):97-102.

6. Mpala L, Chikowe G, Cock IE. No evidence of antiseptic properties and low toxicity of selected Aloe species. Journal of Pharmaceutical Negative Results. 2010;1(1):10. https://doi.org/10.4103/0976-9234.68869.

7. Kumar GP, Khanum F. Neuroprotective potential of phytochemicals. Pharmacognosy Reviews. 2012;6(12):81. https://doi.org/10.4103/09737847.99898 ; PMid:23055633 PMCid:PMC3459459.

8. Hawkins KM, Smolke CD. Production of benzylisoquinoline alkaloids in Saccharomyces cerevisiae. Nature Chemical Biology. 2008;4(9):564-73. https://doi.org/10.1038/nchembio.105;PMid:18690217PMCid:PMC2830865.

9. Onoyovwe A, Hagel JM, Chen X, Khan MF, Schriemer DC, Facchini PJ. Morphine biosynthesis in opium poppy involves two cell types: sieve elements 
and laticifers. The Plant Cell. 2013;25(10):4110-22. https://doi.org/10.1105/ tpc.113.115113; PMid:24104569 PMCid:PMC3877807.

10. Nakagawa A, Minami H, Kim JS, Koyanagi T, Katayama T, Sato F, et al. A bacterial platform for fermentative production of plant alkaloids. Nature Communications. 2011;2:326. https://doi.org/10.1038/ncomms1327 ; PMCid:PMC3112539.

11. Finn KJ. Applications of dihydroarenediols to chemoenzymatic synthesis: approaches to total synthesis of morphine alkaloids. 2006.

12. Cengiz M, Dincturk OD, Sahin HT. Fractional extraction and structural characterization of opium poppy and cotton stalks hemicelluloses. Pharmacognosy Magazine. 2010;6(24):315. https://doi.org/10.4103/09731296.71798; PMid:21120035 PMCid:PMC2992146.

13. Leisch $\mathrm{H}$, Omori AT, Finn KJ, Gilmet J, Bissett $\mathrm{T}$, Ilceski $\mathrm{D}$, et al. Chemoenzymatic enantiodivergent total syntheses of (+)-and (-)-codeine. Tetrahedron. 2009;65(47):9862-75. https://doi.org/10.1016/j.tet.2009.09.052.

14. Mizukami H, Hayashi H. Biosynthesis and biotransformation. Transgenic Crop Plants: Springer; 2010. p. 251-74. https://doi.org/10.1007/978-3-64204809-8_9; PMid:20210747.

15. Seidi S, Yamini Y, Heydari A, Moradi M, Esrafili A, Rezazadeh M. Determination of thebaine in water samples, biological fluids, poppy capsule, and narcotic drugs, using electromembrane extraction followed by high-performance liquid chromatography analysis. Analytica Chimica Acta. 2011;701(2):181-8. https://doi.org/10.1016/j.aca.2011.05.042; PMid:21801886.

16. Rao SR, Tripathi U, Ravishankar G. Biotransformation of codeine to morphine in freely suspended cells and immobilized cultures of Spirulina platensis. World Journal of Microbiology and Biotechnology. 1999;15(4):465-9. https:// doi.org/10.1023/A:1008975901642.

17. Carroll RJ, Leisch H, Rochon L, Hudlicky T, Cox DP. One-pot conversion of thebaine to hydrocodone and synthesis of neopinone ketal. The Journal of Organic Chemistry. 2008;74(2):747-52. https://doi.org/10.1021/jo802454v; PMid:19072148.

18. Desgagné-Penix I, Facchini PJ. Benzylisoquinoline alkaloid biosynthesis. Plant Metabolism and Biotechnology. 2011:241-61. https://doi. org/10.1002/9781119991311.ch9.

19. Nyman U, Bruhn JG. Papaver bracteatum-a summary of current knowledge. Planta Medica. 1979;35(02):97-117. https://doi.org/10.1055/s-0028-1097192; PMid:419192.

20. Seddigh M, Jolliff GD, Calhoun W, Crane JM. Papaver bracteatum, potential commercial source of codeine. Economic Botany. 1982;36(4):433-41. https:// doi.org/10.1007/BF02862702.

21. Hodges CC, Horn JS, Rapoport H. Morphinan alkaloids in Papaver bracteatum: Biosynthesis and fate. Phytochemistry. 1977;16(12):1939-42. https://doi.org/10.1016/0031-9422(77)80100-3.

22. Chaudhary V. Fungal biotransformation of morphine alkaloids. 2009.

23. Patra S. Biotransformation of Caffeine to Value Added Products: University of Mysore. 2007.

24. Rathbone DA, Bruce NC. Microbial transformation of alkaloids. Current Opinion in Microbiology. 2002;5(3):274-81. https://doi.org/10.1016/S13695274(02)00317-X.

25. Hailes AM, Bruce NC. Biological synthesis of the analgesic hydromorphone, an intermediate in the metabolism of morphine, by Pseudomonas putida M10. Applied and Environmental Microbiology. 1993;59(7):2166-70. PMid:7689317 PMCid:PMC182252.

26. Madyastha K, Reddy G, Nagarajappa H, Sridhar G. N-Demethyhitlon and $\mathrm{N}$-oxidation of thebaine, an isoquinoline alkaloid by Mucor piriformis. Indian Journal of Chemistry. 2000;39:377-81.
27. Kyslíková E, Babiak P, Štěpánek V, Zahradník J, Palyzová A, Marešová $H$, et al. Biotransformation of codeine to $14-\mathrm{OH}$-codeine derivatives by Rhizobium radiobacter R89-1. Journal of Molecular Catalysis B: Enzymatic. 2013;87:1-5. https://doi.org/10.1016/j.molcatb.2012.10.004.

28. Niknam S, Faramarzi MA, Abdi K, Yazdi MT, Amini M, Rastegar H. Bioconversion of codeine to semi-synthetic opiate derivatives by the cyanobacterium Nostoc muscorum. World Journal of Microbiology and Biotechnology. 2010;26(1):119-23. https://doi.org/10.1007/s11274-0090150-z.

29. Long MT, Hailes AM, Kirby GW, Bruce NC. Transformations of morphine alkaloids by Pseudomonas putida M10. Applied and Environmental Microbiology. 1995;61(10):3645-9. PMid:7487001 PMCid:PMC167664.

30. Boonstra B, Rathbone DA, Bruce NC. Engineering novel biocatalytic routes for production of semisynthetic opiate drugs. Biomolecular Engineering. 2001;18(2):41-7. https://doi.org/10.1016/S1389-0344(01)00084-3.

31. Bruce NC, Wilmot CJ, Jordan KN, Trebilcock AE, Stephens LDG, Lowe CR. Microbial degradation of the morphine alkaloids: identification of morphinone as an intermediate in the metabolism of morphine by Pseudomonas putida M10. Archives of Microbiology. 1990;154(5):465-70. https://doi.org/10.1007/ BF00245229; PMid: 1701625.

32. Kunz DA, Reddy GS, Vatvars A. Identification of transformation products arising from bacterial oxidation of codeine by Streptomyces griseus. Applied and Environmental Microbiology. 1985;50(4):831-6. PMid:3936418 PMCid:PMC291756.

33. Asha S, Vidyavathi M. Cunninghamella-a microbial model for drug metabolism studies-a review. Biotechnology Advances. 2009;27(1):16-29. https://doi.org/10.1016/j.biotechadv.2008.07.005 ; PMid:18775773.

34. Venisetty R, Keshetty S, Ciddi V. Biotransformation of silibinin (silybin) using fungal organisms. Indian Journal of Pharmacy Education and Research. 2011:45(4):384-91.

35. Stabler PJ, Holt PJ, Bruce NC. Transformation of 2, 2'-Bimorphine to the Novel Compounds 10- $\alpha$-S-Monohydroxy-2, 2'-Bimorphine and 10, 10'- $\alpha, \alpha^{\prime}-\mathrm{S}$, $S^{\prime}$-Dihydroxy-2, 2'-Bimorphine byCylindrocarpon didymum. Applied and Environmental Microbiology. 2001;67(8):3716-9. https://doi.org/10.1128/ AEM.67.8.3716-3719.2001; PMid:11472953 PMCid:PMC93077.

36. Liras $\mathrm{P}$, Umbreit $\mathrm{W}$. Transformation of morphine by resting cells and cellfree systems of Arthrobacter sp. Applied Microbiology. 1975;30(2):262-6. PMid:240309 PMCid:PMC187164.

37. Liras P, Kasparian SS, Umbreit WW. Enzymatic transformation of morphine by hydroxysteroid dehydrogenase from Pseudomonas testosteroni. Applied Microbiology. 1975;30(4):650-6. PMid:172013 PMCid:PMC187243.

38. Ataee N, Fooladi J, Namaei MH, Rezadoost H, Mirzajani F. Biocatalysts screening of Papaver bracteatum flora for thebaine transformation to codeine and morphine. Biocatalysis and Agricultural Biotechnology. 2017;9:127-33. https://doi.org/10.1016/j.bcab.2016.12.006.

39. Liscombe DK, Facchini PJ. Evolutionary and cellularwebs in benzylisoquinoline alkaloid biosynthesis. Current Opinion in Biotechnology. 2008;19(2):173-80. https://doi.org/10.1016/j.copbio.2008.02.012; PMid:18396034.

40. Wilhelm R, Zenk MH. Biotransformation of thebaine by cell cultures of Papaver somniferum and Mahonia nervosa. Phytochemistry. 1997;46(4):701-8. https://doi.org/10.1016/S0031-9422(97)00334-8.

41. Srinivasan A, Bach H, Sherman DH, Dordick JS. Bacterial P450-catalyzed polyketide hydroxylation on a microfluidic platform. Biotechnology and Bioengineering. 2004;88(4):528-35. https://doi.org/10.1002/bit.20285; PMid:15459906. 


\section{PICTORIAL ABSTRACT}

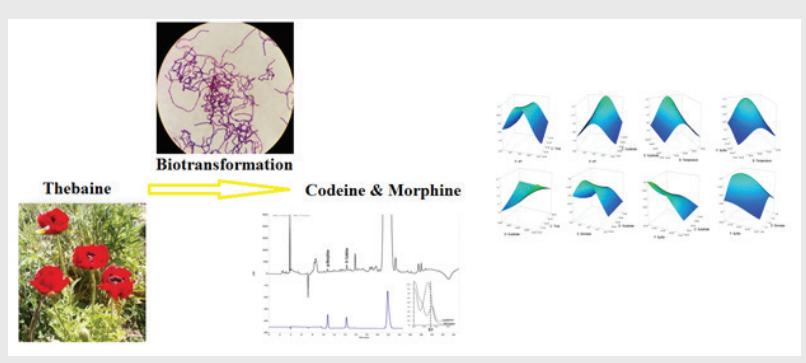

\section{About Authors}

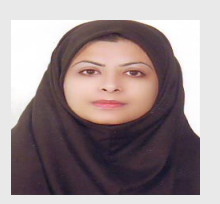

Nazanin Ataee: She is pursuing PhD in microbiology, faculty of biology science, Alzahra university, Vanak, Tehran, Iran. She has 10 years teaching experience in Birjand university. She has published one book and various research articles in international and national journals to her credit. Her research area of interest is pharmaceutical biotechnology.
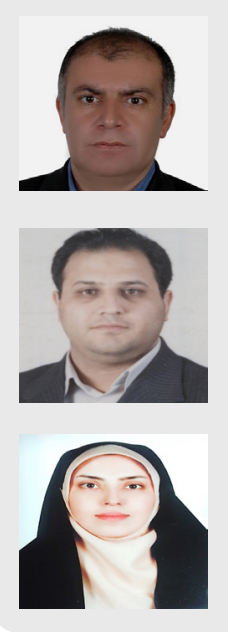

Fateme Mirzajani: She received the M.Sc. degrees in phytochemistry fromthe Shahid Beheshti University, Tehran, in 2007. She is currently working toward the Ph.D. degree in phytochemistry in the field of Nano toxicology and proteomics from Medical Plants and Drug Research Institute, Shahid Beheshti University. She is currently a university Professor in the field of Nanotechnology and protein research with Shahid Beheshti University.

Cite this article: Ataee N, Fooladi J, Namaei MH, Mirzajani F. Response surface methodology optimization of thebaine biotransformation into codeine and morphine using Bacillus sp. FAR. Indian J of Pharmaceutical Education and Research. 2017;51(4):684-91. 